\title{
Evaluation of Arsenic Trioxide Potential for Lung Cancer Treatment: Assessment of Apoptotic Mechanisms and Oxidative Damage
}

\section{Alice M Walker ${ }^{1}$, Jacqueline J Stevens ${ }^{1}$, Kenneth Ndebele ${ }^{2}$ and Paul B Tchounwou ${ }^{3 *}$}

${ }^{1}$ Molecular and Cellular Biology Research Laboratory, Jackson State University, Jackson, Mississippi, USA

${ }^{2}$ Laboratory of Cancer Biology and Target Validation, Jackson State University, Jackson, Mississippi, USA

${ }^{3}$ Molecular Toxicology Research Laboratory, NIH-Center for Environmental Health, College of Science, Engineering and Technology, Jackson State University, Jackson, Mississippi, USA

\section{Abstract}

Background: Lung cancer is one of the most lethal and common cancers in the world, causing up to 3 million deaths annually. The chemotherapeutic drugs that have been used in treating lung cancer include cisplatinpemetrexed, cisplastin-gencitabinoe, carboplatin-paclitaxel and crizotinib. Arsenic trioxide (ATO) has been used in the treatment of acute promyelocytic leukemia. However, its effects on lung cancer are not known. We hypothesize that ATO may also have a bioactivity against lung cancer, and its mechanisms of action may involve apoptosis, DNA damage and changes in stress-related proteins in lung cancer cells.

Methods: To test the above stated hypothesis, lung carcinoma (A549) cells were used as the test model. The effects of ATO were examined by performing 6-diamidine-2 phenylindole (DAPI) nuclear staining for morphological characterization of apoptosis, flow cytometry analysis for early apoptosis, and western blot analysis for stressrelated proteins (Hsp70 and cfos) and apoptotic protein expressions. Also, the single cell gel electrophoresis (Comet) assay was used to evaluate the genotoxic effect.

Results: ATO-induced apoptosis was evidenced by chromatin condensation and formation of apoptotic bodies as revealed by DAPI nuclear staining. Cell shrinkage and membrane blebbing were observed at $4 \mathrm{and} 6 \mu \mathrm{g} / \mathrm{ml}$ of ATO. Data from the western blot analysis revealed a significant dose-dependent increase $(p<0.05)$ in the Hsp 70 , caspase 3 and p53 protein expression, and a significant $(p<0.05)$ decrease in the cfos, and bcl-2 protein expression at 4 and $6 \mu \mathrm{g} / \mathrm{ml}$ of ATO. There was a slight decrease in cytochrome c protein expression at 4 and $6 \mu \mathrm{g} /$ $\mathrm{ml}$ of ATO. Comet assay data revealed significant dose-dependent increases in the percentages of DNA damage, Comet tail lengths, and Comet tail moment.

Conclusion: Taken together our results indicate that ATO is cytotoxic to lung cancer cells and its bioactivity is associated with oxidative damage, changes in cellular morphology, and apoptosis.

Keywords: Arsenic trioxide; A549 cells; Oxidative stress; Hsp70; c-fos; p53; bcl-2; Apoptosis; Genotoxicity

\section{Background}

Lung cancer is one of the most lethal and common of cancers in the world, causing up to 3 million deaths, annually [1,2]. Only one in ten patients diagnosed with lung cancer has a survival of 5 years [3]. It is a leading cause of cancer death in men and women in the United States and more people die from lung cancer than any other type of cancer. The chemotherapeutic drugs that are currently being used in treating lung cancer are cisplatin-pemetrexed, cisplastin-gencitabinoe, carboplatin-paclitaxel and crizotinib [4]. However, the prognosis is still poor despite advances in present therapies. There is still a need for more effective treatment strategies.

Arsenic trioxide (ATO) has been used as an anticancer agent in traditional Chinese medicine for many years. In vitro studies have also demonstrated that ATO exerts its therapeutic mechanisms through a multitude of biochemical events including cell cycle modulation and apoptosis in leukemia cell. Recently, the Food and Drug Administration has approved ATO, the trade name Trisenox as a chemotherapeutic agent for the treatment of relapsed/refractory acute promyelocytic leukemias, head and neck cancer neuroblastoma [5-8].

Apoptosis is an active and gene-directed form of cell death. The role of apoptosis is to maintain tissue homeostasis and to eliminate excess or dysfunctional cells. Its biochemical features include activation of caspase cascade and the cleavage of various caspase substrates such as caspase 3 and caspase 9 [9-11]. Morphologically, apoptosis is characterized by cellular and nuclear shrinkage as well as budding or blebbing which leads to the pinching off of blebs giving rise to "apoptotic bodies", and chromatin condensation [10,11]. In addition, apoptosis is accompanied by internucleosomal DNA fragmentation giving rise to the classical "ladder" pattern on DNA electrophoresis $[12,13]$. In apoptosis, the functional integrity of the plasma membrane is long maintained.

Studies have shown that ATO induces apoptosis not only in leukemic and hematologic cells but also in solid tumors such as breast [14,15], neuroblastoma, [16]; murine lung [17-21], and bladder $[22,23]$. The apoptotic effects of ATO in these cell lines and solid tumors have been shown to be regulated through either the intrinsic or the extrinsic pathway. ATO has been found to be genotoxic in human cells such as pluripotent stem cells, keratinocytes, dendritic

${ }^{*}$ Corresponding author: Paul B. Tchounwou, Sc.D. Presidential Distinguished Professor and Associate Dean, CSET, Jackson State University, 1400 Lynch Street, P.O. Box 18540, Jackson, Mississippi, USA, Tel: (601)979-0777; Fax (601)979-0570; E-mail: paul.b.tchounwou@jsums.edu

Received September 18, 2015; Accepted January 18, 2016; Published January 20, 2016

Citation: Walker AM, Stevens JJ, Ndebele K, Tchounwou PB (2016) Evaluation of Arsenic Trioxide Potential for Lung Cancer Treatment: Assessment of Apoptotic Mechanisms and Oxidative Damage. J Cancer Sci Ther 8: 001-009. doi:10.4172/1948-5956.1000379

Copyright: (c) 2016 Walker AM, et al. This is an open-access article distributed under the terms of the Creative Commons Attribution License, which permits unrestricted use, distribution, and reproduction in any medium, provided the original author and source are credited. 
cells, and melanocytes [24, 25], leukemia cells [26], and hepatocellular carcinoma cells [27]. Arsenic compounds have been known to inhibit DNA repair, and induce chromosomal aberrations, sister chromatid exchanges and micronuclei formation in mammal cells. Several studies have been reported on the genotoxic potential of ATO and other arsenic compounds [26,27]. In vitro and in vivo studies that inorganic arsenic increases the frequency of micronuclei, chromosome aberrations, and sister chromatid exchanges in both animals and humans, however it does not induce point mutations [26-28].

Although studies on the effect of ATO on lung cancer cell lines are scarce, it is likely that this leukemia treatment drug may also have a bioactivity against lung cancer. Therefore, the study was designed to assess the potential for its use as a chemotherapeutic agent for the treatment of lung cancer; by investigating its oxidative, genotoxic and apoptotic mechanisms of action on A549 cells.

\section{Materials and Methods}

\section{Cell line and chemicals}

The human lung carcinoma cell line (A549), F-12 K medium, and trypan blue were purchased from American Type Culture Collection (ATCC) (Manassas, VA). The fetal bovine serum (FBS), penicillin/ streptomycin/fungizone, phosphate buffered saline (PBS) and trypsin versene were purchased from Invitrogen (Grand Island, NY). ATO was purchased from Fisher Scientific (Houston, TX). P53 anti-mouse, bcl-2 anti-mouse, bcl-2 anti-rabbit, cytochrome c anti-mouse, hsp70 anti-mouse, caspase- 3 anti-mouse and goat anti-mouse horseradish peroxidase (HRP) conjugated goat anti-rabbit (HRP) antibodies were purchased from EMD Biosciences (San Diego, CA). 4, 6-diamidine phenylindole (DAPI) stain was purchased from Invitrogen (Carlsbad, CA). Prolong gold antifade permount containing $1 \mu \mathrm{g} / \mathrm{ml}$ of DAPI was purchased from Molecular Probe (Eugene, OR). C-fos anti-rabbit antibody was purchased from Santa Cruz Biosciences (Santa Cruz, CA). ECL western blotting detection system reagents and film (CXposure) were purchased from Thermo Scientific/Pierce (Rockford, IL). The caspase 3-FITC and Annexin V-FITC assay kits were purchased from BD Pharmingen (San Diego, CA). The folin-phenol (DC) protein determination kit, cell lysis buffer, and non-fat milk were obtained from BioRad Laboratories (Hercules, CA). Polyvinylidene difluoride (PVDF) membrane, one-chamber glass slides, and comet assay kit from Millipore (Bedford, MA), (Lab-Tek Nunc, Naperville, IL), Trevigen Incorporation (Gaithersburg, MD), respectively.

\section{Cell culture}

Human lung carcinoma (A549) cells were maintained in F12-K complete growth medium supplemented with $10 \%$ FBS and $1 \%$ penicillin $(10,000$ units $/ \mathrm{ml}) /$ streptomycin $(10,000$ units $/ \mathrm{ml})$ (pen-strep) mixture as adherent cells. Cells were then grown in a humidified incubator under an atmosphere of $95 \%$ air and $5 \% \mathrm{CO} 2$ at $37^{\circ} \mathrm{C}$ to subconfluence $(80-95 \%)$. The culture medium was replaced every $48 \mathrm{hr}$. After growing to $80-95 \%$ confluence, the medium was aspirated and the monolayer was washed three times with sterile phosphate buffered saline. The cell monolayer was treated with $1 \mathrm{ml} 0.25 \%$ trypsin- 0.5 mM EDTA per plate and incubated briefly at $37^{\circ} \mathrm{C}$. The cells were then viewed microscopically to ensure a complete cell detachment. Cells were re-suspended in F12-K complete growth medium, stained with $0.4 \%$ trypan blue ( 1 to $2 \mathrm{~min}$ ) and then counted with a hemacytometer. The cells were seeded at a density of $5 \times 105$ cells on $13 \times 100 \mathrm{~mm}$ tissue cultured plates prior to treatment with arsenic trioxide.

\section{Nuclear staining with 4', 6-diamidine phenylindole (DAPI)}

Cell morphology was evaluated by Olympus 1X71 fluorescence microscopy following (DAPI) staining. The cells were cultured in onechamber glass slides (Lab-Tek Nunc, Naperville, IL). After treatment with $0,2,4$, and $6 \mu \mathrm{g} / \mathrm{ml}$ of arsenic trioxide for $48 \mathrm{hr}$, the slides were rinsed with PBS and fixed in PBS containing 3.7\% paraformaldehyde for $30 \mathrm{~min}$. After fixation, the slides were washed twice with PBS. Three drops of Prolong Gold anti-fade permount containing $(1 \mu \mathrm{g} / \mathrm{ml})$ of DAPI stain (Molecular Probe, Eugene, OR) were added to the slides and the slides were placed in the dark until later. The slides were then visualized using an Olympus Epifluorescence microscope equipped with a Spot Imaging camera (Diagnostic Instruments, Sterling, Height, MI) using the DAPI filter [29].

\section{Annexin V-FITC assay}

To evaluate the effect of arsenic trioxide on early apoptosis, the Annexin V-FITC assay (BD Pharmingen) was performed according to a previous described protocol [30-33]. Briefly, A549 cells were seeded at a density of $3 \times 10^{5}$ cells in F12-K complete medium on $13 \times 100$ $\mathrm{mm}$ tissue treated plates, and grown to $60-70 \%$ confluence. Cells were serum starved overnight in 1\% FBS in F12-K medium supplemented with $1 \%$ penicillin/streptomycin. The serum medium was removed. The cells were reintroduced to F12-K complete medium, and treated with ATO at $0,2,4$, and $6 \mu \mathrm{g} / \mathrm{ml}$ for $48 \mathrm{hr}$. The cells were washed twice with cold PBS and then resuspended in $1 \mathrm{X}$ binding buffer [10 $\mathrm{mM}$ Hepes/ $\mathrm{NaOH}$ (pH 7.4), $140 \mathrm{mM} \mathrm{NaCl}$, and $2.5 \mathrm{mM} \mathrm{CaCl}_{2}$ ]. The cells $(100 \mu \mathrm{L})$ were transferred to a $5 \mathrm{ml}$ culture tube and $5 \mu \mathrm{L}$ of Annexin V-FITC and $5 \mu \mathrm{L}$ propidium iodide. The cells were vortexed and incubated for $15 \mathrm{~min}$ at room temperature $\left(25^{\circ} \mathrm{C}\right)$ in the dark. Four hundred micro-liters of binding buffer (1X) was added to the tubes, analyzed and counted at 10,000 counts using a fluorescence-activated cell-sorting (FACS-Vantage) system (Becton-Dickinson, San Jose, CA).

\section{Caspase 3-FITC Assay}

To assess the effect of arsenic trioxide on late apoptosis, caspase- 3 assay was performed by flow cytometry according to previously described protocols [34-36] using a commercially available caspase-3 FITC assay kit (BD Pharmingen). A549 cells were seeded at a density of $3 \times 10^{5}$ cells into F12-K complete medium on $13 \times 100 \mathrm{~mm}$ tissue treated plate and grown to $60-70 \%$ confluence in 3 days. Sub-confluent cells were serum starved overnight. The cells were re-introduced to F12-K complete medium and treated with arsenic trioxide at $0,2,4$, and $6 \mu \mathrm{g} / \mathrm{ml}$, respectively for $48 \mathrm{hr}$. After exposure, cells were washed twice with cold PBS and resuspended in BD Cytofix/Cytoperm (neutral $\mathrm{pH}$-buffed saline, saponin and $4 \%(\mathrm{w} / \mathrm{v})$ paraformaldehyde) at a concentration of $1 \times 10^{6}$ cells $/ 0.5 \mathrm{ml}$. The cells were incubated for $20 \mathrm{~min}$ on ice. The cells were pelleted and the BD Cytofix/Cytoperm solution was aspirated and discarded. The cells were washed twice with BD Perm/Wash buffer at room temperature. The cells were resuspended in BD Perm/Wash buffer plus antibody and incubated for $30 \mathrm{~min}$ at room temperature. The pellets were resuspended in BD Perm/Wash buffer and analyzed and counted at 10,000 counts on the fluorescence-activated cell-sorting (FACS-Vantage) system (BectonDickinson, San Jose, CA).

\section{Preparation of cell lysates and western blot analysis}

To assess the effects of ATO on protein expression, A549 cells were washed with PBS. The washed cells were lysed in a cell lysis buffer [20 mM Tris, $150 \mathrm{mM} \mathrm{NaCl}, 1 \mathrm{mM}$ EDTA, $1 \mathrm{mM}$ EGTA, $1 \%$ Triton $\mathrm{X}-100,2.5 \mathrm{mM}$ sodium pyrophosphate, $1 \mathrm{mM} \beta$-glycerophosphate, 
$1 \mathrm{mM} \mathrm{Na}_{3} \mathrm{VO}_{4}, 1 \mu \mathrm{g} / \mathrm{ml}$ leupeptin and $1 \mathrm{mM}$ phenylsulfonyl fluoride (PMSF)], and the lysates were centrifuged at $13,000 \mathrm{x} g$ for $10 \mathrm{~min}$. The supernatant was quantified and used for Western blot analysis. The protein concentrations were measured by folin-phenol (DC) protein reagent [37] using bovine serum albumin as a standard. Cell lysate containing $100 \mu \mathrm{g} / 20 \mu \mathrm{L}$ of the protein was fractionated on $10 \%$ SDS-PAGE gel. The proteins were transferred onto a polyvinylidene difluoride (PVDF) membrane (Millipore, Bedford, MA) at a constant current of $400 \mathrm{~mA}$ overnight at $4^{\circ} \mathrm{C}$. The membranes were blocked with $10 \%$ non-fat milk (Bio-Rad) in PBS containing $0.05 \%$ Tween-20 (PBST) for at least $1 \mathrm{hr}$ at room temperature. The membranes were subsequently probed overnight at $4{ }^{\circ} \mathrm{C}$ with anti-p53 ab-6 (1:500), anti-bcl-2 (1:250), anti-caspase 3 (1:1000), anti-Hsp 70 (1:1000), anti-cytochrome c $(1: 1000)$ primary antibody (EMD Biosciences, La Jolla, CA), and anti-cfos rabbit (1:1000) primary antibody (Cell Signaling Technology, Danver, MA) in primary antibody dilution buffer ( $1 \%$ nonfat milk in PBST). After the membranes were washed three times in PBST, they were incubated for $1 \mathrm{hr}$ at room temperature with horseradish peroxidase (HRP) conjugated anti-mouse or antirabbit goat secondary antibodies (EMD Biosciences, La Jolla, CA) at a 1:10,000 dilution in PBST. The protein bands were detected with enhanced chemiluminescence (ECL-plus) western blotting detection system (GE Biosciences, Piscataway, NJ). Membranes were exposed to blue CXposure film (Thermo-Fisher Scientific, Houston, TX) and visualized by autoradiography using Kodak X-OMAT Processor (MidSouth Medical Imaging, Flowood, MS).

\section{Single cell gel electrophoresis (comet) assay}

A549 cells were seeded on $13 \times 100 \mathrm{~mm}$ tissue culture dishes at a density of $3 \times 10^{5}$ cells per well in complete growth medium and grown to $70-75 \%$ confluence in a humidified incubator under an atmosphere of $95 \%$ air and $5 \% \mathrm{CO}_{2}$ at $37^{\circ} \mathrm{C}$. Sub-confluent cells were incubated in $1 \%$ fetal bovine serum supplemented with $1 \%$ antibiotic for $24 \mathrm{hr}$ prior to treatment. Afterward, the cells were reintroduced into complete growth medium supplemented with $0,2,4$, and $6 \mu \mathrm{g} / \mathrm{ml}$ of arsenic trioxide for $48 \mathrm{hr}$. Cells incubated in complete growth medium served as a control. After $48 \mathrm{hr}$, the comet assay was performed following the manufacture protocol [38]. Following ATO treatment, the medium was removed and the cells were washed three times with PBS, trypsinized with $1 \mathrm{ml}$ of $0.25 \%$ trypsin-EDTA, harvested, and counted. The cells were spun down at $3000 \mathrm{rpm}$ for $5 \mathrm{~min}$. The pellet was resuspended in PBS at a cell density of $1 \times 105$. The cells were combined with molten LMAgarose $\left(42^{\circ} \mathrm{C}\right)$ at a ratio of $1: 10(\mathrm{v} / \mathrm{v})$, and $75 \mu \mathrm{l}$ was immediately pipetted onto Cometslide ${ }^{\mathrm{TM}}$. The comet slides were placed flat in a $4^{\circ} \mathrm{C}$ refrigerator for $30 \mathrm{~min}$ and then immersed in pre-chilled lysis solution on ice for $1 \mathrm{hr}$. The lysis buffer was removed, and the slides were immersed in freshly prepared alkaline solution, $\mathrm{pH}>13$ for $1 \mathrm{hr}$. Slides were washed twice for 5 min with 1 X TBE (Tris boric acid EDTA) and electrophoresed at $1 \mathrm{volt} / \mathrm{cm}(22 \mathrm{v})$ for $10 \mathrm{~min}$. Slides were placed in $70 \%$ ethanol for $5 \mathrm{~min}$. The excess ethanol was removed. Slides were air dried overnight, stained with SYBRgreen, and allowed to set for $12 \mathrm{hr}$. The comet slides were viewed and analyzed using the Olympus Epifluorescence Microscope with LAI's Automated Comet Analysis Scoring System software (Loates Associates, Inc. Westminster, MD). A total of 150 comets were scored per arsenic trioxide dose. Seventyfive comets were randomly selected from three replicated slides. The experiment was repeated three times.

\section{Statistical analysis}

Experiments were carried out in triplicates, and the data were presented as means \pm SDs. To test for differences among and between experimental groups, one-way analysis of variance (ANOVA) and Student's t-test were performed respectively, using SAS software available in the Biostatistics Core Laboratory available at the RCMI Center for Environmental Health at Jackson State University for testing differences. Data were considered statistically significant for $\mathrm{p}$-values less than 0.05 .

\section{Results}

Effect of arsenic trioxide on morphological and apoptotic-related changes in A549 cells.

There are classical changes on cells that undergo apoptosis. Cell shrinkage, membrane blebbing and chromatin condensation were identified as the morphological hallmarks for apoptosis. We examined apoptotic features of A549 cells treated with ATO and untreated A549 cells. The phase contrast micrograph of untreated A549 cells revealed healthy cells also the micrograph revealed round distinctive nuclei with intact cytoplasm (Figures 1A-B). The phase contrast observation revealed that A549 cells treated with ATO showed evidence of cell shrinkage (Figure 1C), membrane blebbing and condensed chromatin (Figure 1D).

The nuclear morphology changes were assessed by DAPI staining. DAPI permeates the plasma membrane and yields blue chromatin Viable cells displayed normal nuclear size and blue fluorescence as shown in Figure 2A. ATO-treated cells showed evidence of apoptosis as characterized by the cell nuclei undergoing fragmentation forming apoptotic bodies and the chromatin being condensed (Figures 2B-D).

\section{Effect of arsenic trioxide on early apoptosis}

To assess the effect of arsenic trioxide on early apoptosis in

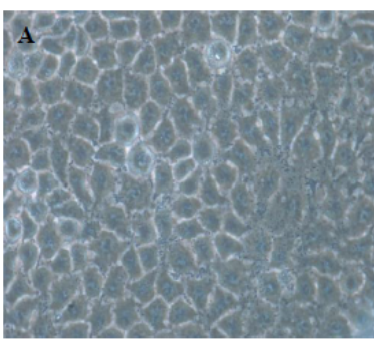

$0 \mu \mathrm{g} / \mathrm{ml}$

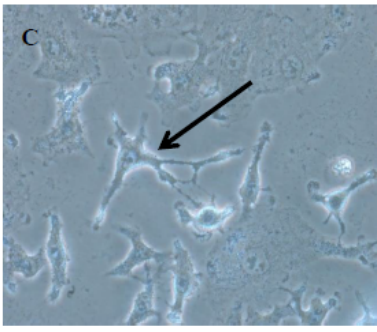

$4 \mu \mathrm{g} / \mathrm{ml}$

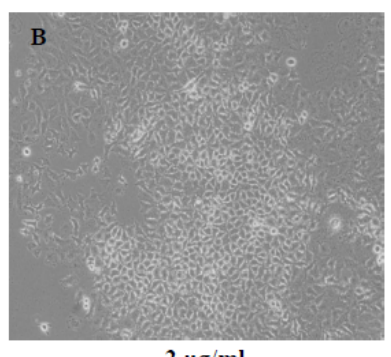

$2 \mu \mathrm{g} / \mathrm{ml}$

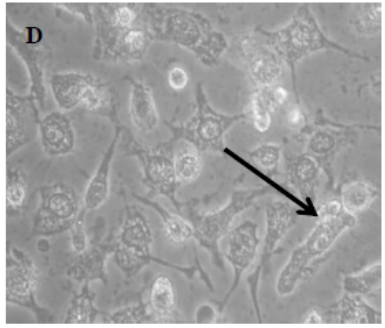

$6 \mu \mathrm{g} / \mathrm{ml}$
Figure 1: Morphological changes of A549 lung cancer cells after $48 \mathrm{hr}$ ATO exposure. A-Untreated control; B - $2 \mu \mathrm{g} / \mathrm{ml}$ ATO; C - $4 \mu \mathrm{g} / \mathrm{ml}$ ATO; and D $6 \mu \mathrm{g} / \mathrm{ml}$ ATO. A549 cells were observed using an Olympus Inverted Phase Contrast Microscope with camera (C-Squared), at (20x) magnification for , and (40x) magnification for Panel $C$ and Panel D. Cells in Panels $A$ and $B$ maintained normal morphological features. The black arrow shows an example of cell shrinkage in Panel C, and an evidence of chromatin condensation and membrane blebbing in Panel D; bo th of which are indicative of apoptosis. 


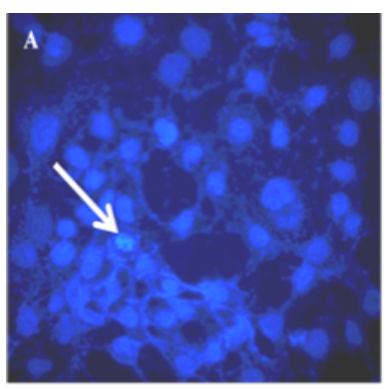

$0 \mu \mathrm{g} / \mathrm{ml}$

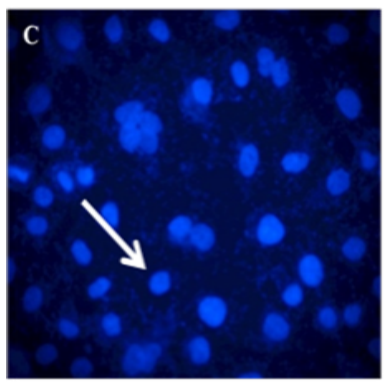

$4 \mu \mathrm{g} / \mathrm{ml}$

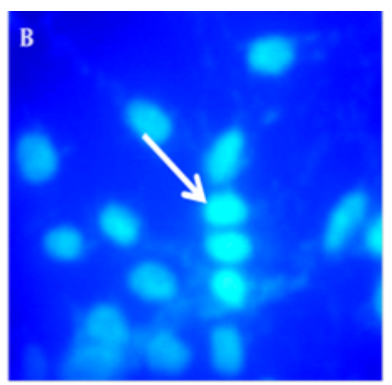

$2 \mu \mathrm{g} / \mathrm{ml}$

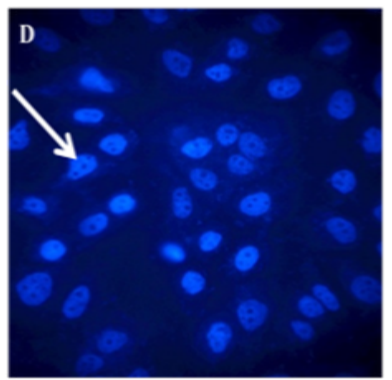

$6 \mu \mathrm{g} / \mathrm{ml}$
Figure 2: Effect of ATO on morphological and apoptotic-related changes in A549 lung cancer cells. The cells were stained with DAPI and visualized on an Olympus Epifluorescence microscope 20X. A549 cells were treated for 48 $\mathrm{hr}$ with ATO at 0 (control), 2, 4 and $6 \mu \mathrm{g} / \mathrm{ml}$ respectively. Panel A $(0 \mu \mathrm{g} / \mathrm{ml})$, the arrow points to a nucleus fluorescing bright blue; Panel B $(2 \mu \mathrm{g} / \mathrm{ml})$, the black arrow indicates viable cells and the white arrow represents a non-viable cell; Panel C $(4 \mu \mathrm{g} / \mathrm{ml})$, the arrows indicate apoptotic nuclei with condensed chromatin; and Panel D $(6 \mu \mathrm{g} / \mathrm{ml})$, the arrow is pointing to apoptotic bodies within the nucleus.

A549 cells treated with ATO, Annexin V-FITC assay was performed. Annexin $\mathrm{V}$ binds to the membrane phospholipid phosphatidylserine that is located within the plasma membrane of apoptotic cells. AnnexinV positive and propidium iodide negative cells were considered to be apoptotic. The histograms in Figure 3A are representations of cell populations. The viable cell populations are represented in the lower left quadrant of the histogram as Annexin V negative and PI negative and the lower right quadrant of the histogram represents apoptotic cells as Annexin $\mathrm{V}$ positive and PI negative. The percentages of viable cells were $89 \%, 56 \%, 66 \%$, and $40 \%$ for $0,2,4$, and $6 \mu \mathrm{g} / \mathrm{ml}$, respectively (Figures 3A-D). The percentages for apoptotic cells were $9.0 \pm 0.50$, $30.00 \pm 0.50,28.00 \pm 0.70$ and $17.00 \pm 0.90$ for $0,2,4$ and $6 \mu \mathrm{g} / \mathrm{ml}$, respectively.

\section{Effect of arsenic trioxide on late apoptosis}

To examine whether caspase- 3 was activated during arsenic trioxide induced apoptosis, a caspase-3 FITC assay was performed. As shown in Figure 4, the flow cytometric data revealed that the percentages of caspase- 3 positive cells were $0.74 \pm 0.19 \%, 1.90 \pm 0.00 \%, 4.60 \pm$ $0.14 \%$ and $10.20 \pm 2.50 \%$ for $0,2,4$, and $6 \mu \mathrm{g} / \mathrm{ml}$ ATO, respectively. Statistically significant differences $(\mathrm{p}<0.05)$ in caspase-3 activity were observed at 4 and $6 \mu \mathrm{g} / \mathrm{ml}$ of ATO when compared to the control.

\section{Effect of arsenic trioxide on the expression of apoptotic and stress proteins}

To validate that arsenic trioxide induced apoptosis, we evaluated

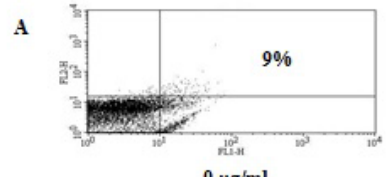

$0 \mu \mathrm{g} / \mathrm{ml}$

C

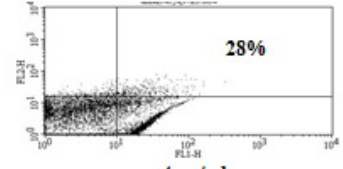

$4 \mu \mathrm{g} / \mathrm{ml}$

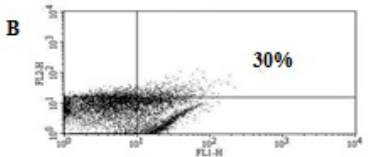

$2 \mu \mathrm{g} / \mathrm{ml}$

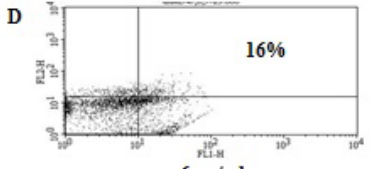

$6 \mu \mathrm{g} / \mathrm{ml}$
E

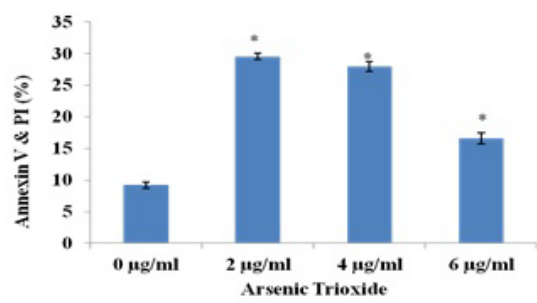

Figure 3: Effect of arsenic trioxide on early apoptosis. Arsenic trioxide induced apoptosis in A549 cells. Propidium iodide (PI) is represented by FL1-H on the $\mathrm{x}$-axis, and annexin V-FITC is represented by FL2-H on the $y$-axis. Viable cells are found in the lower left quadrant (annexin $\mathrm{V}$ and PI negative), apoptotic cells are found in the upper left quadrant (annexin V positive and PI negative), dead cells are found in the upper right quadrant (annexin $\mathrm{V}$ and PI positive), and damaged cells are found in the lower right quadrant (annexin $\mathrm{V}$ negative and $\mathrm{PI}$ positive). Annexin $\mathrm{V}$ conjugated with propidium iodide $(\mathrm{PI})$ revealed dead cells as represented in upper right quadrants (A-D). Data from the Annexin V FITC flow cytometry analysis of ATO $48 \mathrm{hr}$ exposure revealed that the dead cells were significantly different $\left({ }^{*}\right)$ compared to the control $(E)$ using the one-way ANOVA analysis $(p<0.05)$.

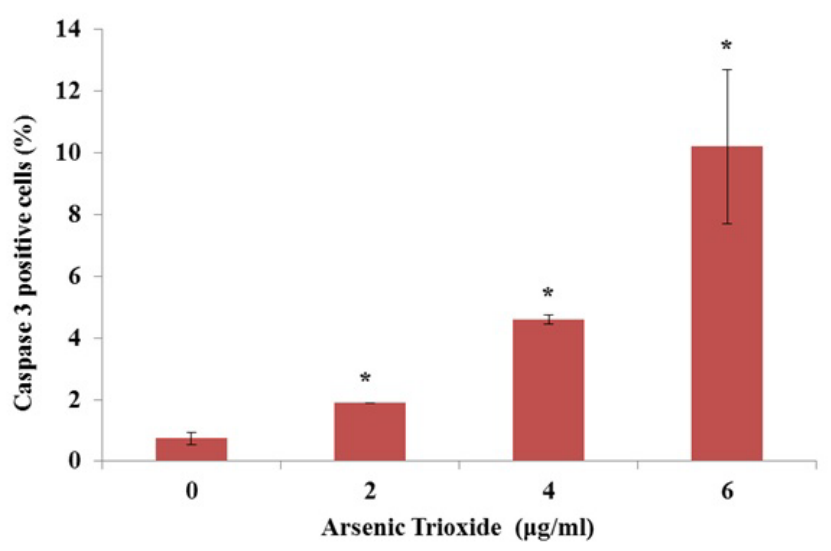

Figure 4: Effect of arsenic trioxide on caspase 3 activity in A549 cells after 48 hr treatment. The data is represented as mean \pm SEM of three experiments performed in triplicates. The differences in mean percentages were considered statistically significant with a $p$ value $<0.05$. The significance of the value is indicated by asterisks $\left({ }^{*}\right)$

the expression of caspase-3, p53, bcl-2, and cytochrome c proteins by Western blot analysis. Study results indicated that caspase- 3 was activated in a dose dependent manner to ATO (Figure 5A). The p53 protein is a determinant in controlling the cell cycle and apoptosis. The p53 protein expression in Figure 5B increased in a dose dependent 
Citation: Walker AM, Stevens JJ, Ndebele K, Tchounwou PB (2016) Evaluation of Arsenic Trioxide Potential for Lung Cancer Treatment: Assessment of Apoptotic Mechanisms and Oxidative Damage. J Cancer Sci Ther 8: 001-009. doi:10.4172/1948-5956.1000379

manner between 0 and $4 \mu \mathrm{g} / \mathrm{ml}$. There was a slight down-regulation of p53 expression at $6 \mu \mathrm{g} / \mathrm{ml}$ of ATO probably due to the high percentage of cell death at higher level of ATO treatment. Western blot analysis revealed that cytochrome c expression substantially increased at $2 \mu \mathrm{g} /$ $\mathrm{ml}$ and down-regulated at 4 and $6 \mu \mathrm{g} / \mathrm{ml}$ of ATO (Figure 5C). Bcl2 expression was significantly decreased in a dose-dependent manner with response ATO treatment (Figure 5D).

To assess whether ATO induces oxidative stress, we tested the expression of $\mathrm{Hsp} 70$ and cfos stress proteins. The western blot analysis revealed a dose-dependent up-regulation of Hsp70 with increasing ATO doses from 0 to $6 \mu \mathrm{g} / \mathrm{ml}$. This was indicative of cells undergoing oxidative stress (Figure 5E). On the other hand, a dose dependent decrease was observed with regard to c-fos expression (Figure 5F).

\section{Genotoxic effects of arsenic trioxide}

To assess the effect of ATO on genotoxicity in A549 cells, singlecell gel electrophoresis (Comet) assay was used to evaluate DNA damage. Comet images in Figures 6A-D displayed the cell DNA migration patterns in A549 cells treated with $0,2,4$, and $6 \mu \mathrm{g} / \mathrm{ml}$ of arsenic trioxide, respectively. The comet tail lengths, percentages DNA damage and olive tail moment were calculated. As shown in Figure 6I (A), the nuclear DNA of untreated cells was perfectly round and retained a highly organized association with matrix proteins in the nucleus. The nuclear DNA of ATO-treated cell was severely fragmented as the dosage increases. Also, the cellular organization was disrupted as depicted Figure 6I (B-D).

The Comet assay data generated from three separate experiments
A
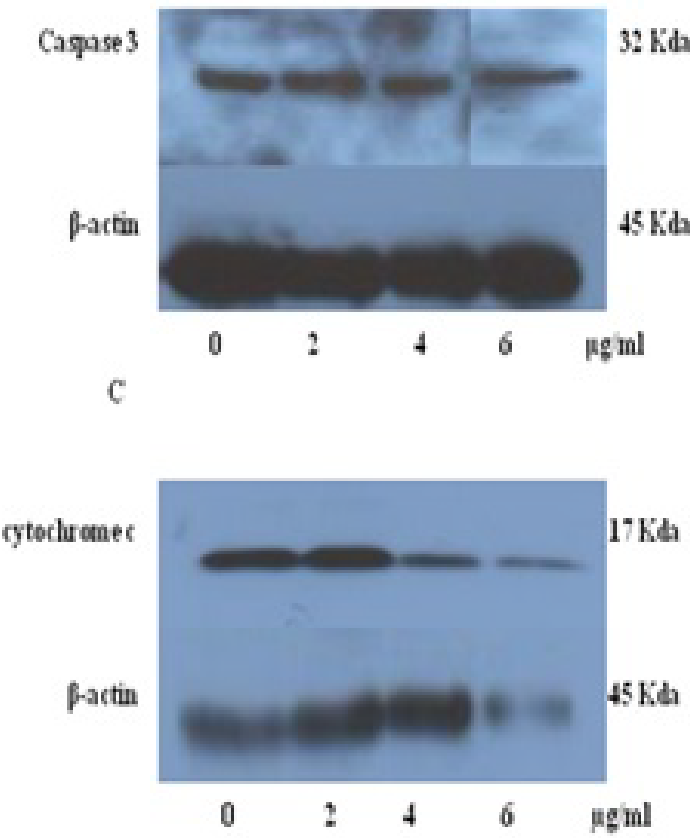

E

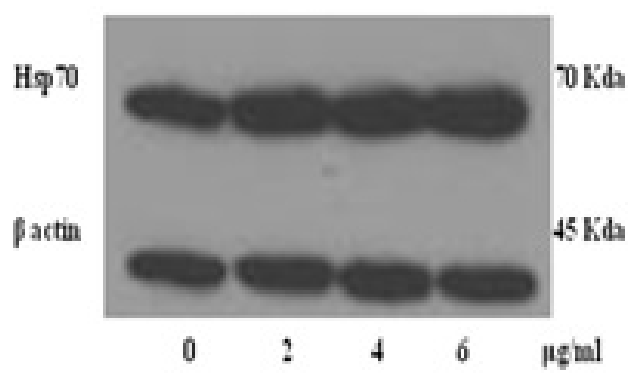

B

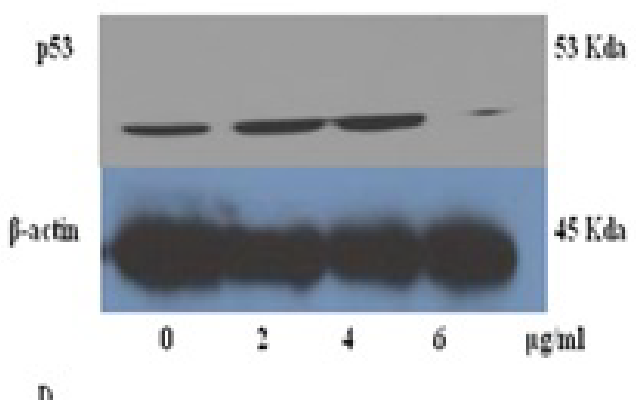

D

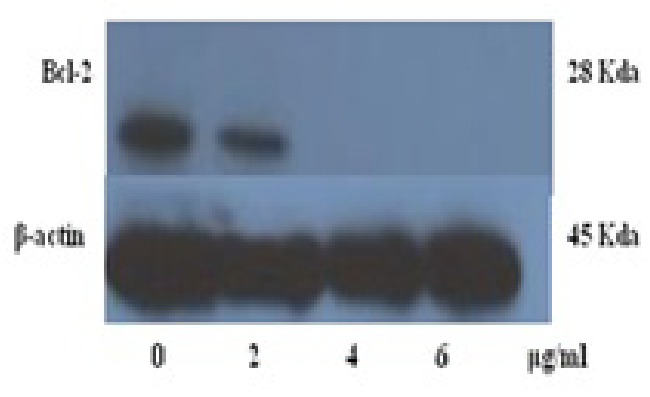

F

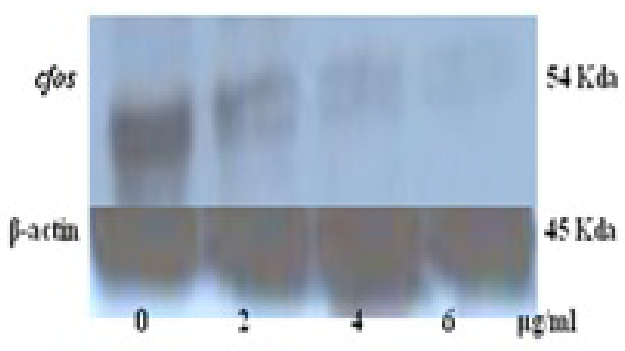

Figure 5: Western blot analysis of expression of apoptotic proteins (A - D) and stress proteins (E - F) ATO-treated A549 cells after 48 hr of exposure. The figures represent: A-caspase 3 expressions; B - p53 expression; C - cytochrome c expression; D - Bcl-2 expression; $\mathrm{E}-\mathrm{Hsp} 70$ expression; and F - cfos expression. 
Citation: Walker AM, Stevens JJ, Ndebele K, Tchounwou PB (2016) Evaluation of Arsenic Trioxide Potential for Lung Cancer Treatment: Assessment of Apoptotic Mechanisms and Oxidative Damage. J Cancer Sci Ther 8: 001-009. doi:10.4172/1948-5956.1000379

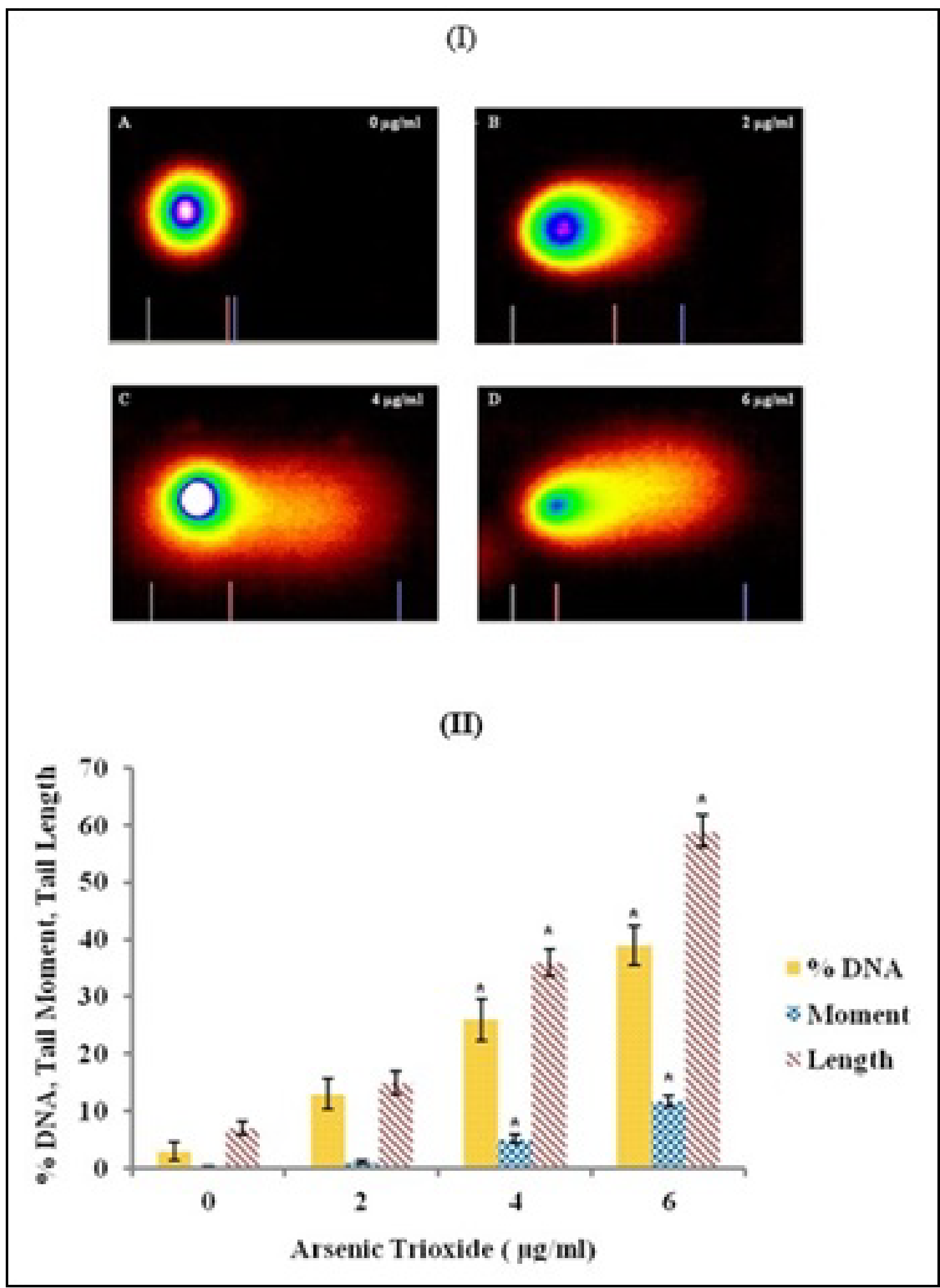

Figure 6: (I) Representation of Comet assay images of A549 cells treated with ATO at $0 \mu \mathrm{g} / \mathrm{ml}$ (A); $2 \mu \mathrm{g} / \mathrm{ml}$ (B), $4 \mu \mathrm{g} / \mathrm{ml}$ (C), and $6 \mu \mathrm{g} / \mathrm{ml}$ (D) after $48 \mathrm{hr}$ of exposure. (II) DNA damage in A549 cells treated with arsenic trioxide. The figure shows the percentages of DNA damage, olive tail moment and Comet tail length.

were analyzed and the mean values of DNA damage, Comet tail length and Comet tail moment were graphically illustrated (Figure 6II). The results show a significant dose-response relationship with regard to
ATO-induced genotoxicity. The percentages of DNA damage were 3.0 $\pm 1.5 \%, 13 \pm 2.7 \%, 26 \pm 3.6 \%$, and $39 \pm 3.4 \%$ for $0,2,4$ and $6 \mu \mathrm{g} / \mathrm{ml}$ of ATO, respectively. The data for Comet tail moment were $0.19 \pm$ 
$0.07,1.06 \pm 0.35,5.1 \pm 0.66$ and $11.7 \pm 0.95$ for $0,2,4$ and $6 \mu \mathrm{g} / \mathrm{ml}$ of ATO, respectively. The data for Comet tail lengths were $7 \pm 1.2 \mu \mathrm{m}$, $15 \pm 2.0 \mu \mathrm{m}, 36 \pm 2.3 \mu \mathrm{m}$ and $57 \pm 2.7 \mu \mathrm{m}$ for $0,2,4$ and $6 \mu \mathrm{g} / \mathrm{ml}$ of ATO, respectively.

\section{Discussion}

Apoptosis assessment is a gene directed tool for understanding developmental biology and tissue homeostasis [39]. In previous study, we demonstrated that ATO has the potential to induce apoptosis in breast cancer and lung cancer cells [40]. In the present study, we observed characteristic apoptosis-related morphological changes in lung cancer cells (A549) exposed to ATO; as shown on the phase contrast micrographs (Figure 1C and 1D) and on the fluorescence micrographs (Figures 2A-D). Furthermore, we also observed a significant increase in the level of externalization of the plasma membrane molecule phosphatidylserine (Figure 3). Li et al. [41] reported other morphological changes in the colon, breast, and pancreatic cancer cell lines after exposure to ATO. These changes included reduced cytoplasmic volume, membrane blebbing, formation of apoptotic bodies and nuclear condensation consistent with apoptosis. To gain an insight into the molecular mechanisms involved in apoptosis caused by ATO in A549 cells, we further evaluated the expression levels of apoptotic-related proteins including caspase 3, p53 and cyctochrome c.

Caspases are a family of proteases which play a pivotal role in the execution of apoptosis [10]. Caspase-3 was used as a biomarker for apoptosis in this study. It was observed that caspase- 3 activity increased in ATO-treated cells a dose-dependent manner (Figure 4A). Previous studies have shown that caspase-3 plays an essential role as an executor of apoptosis [11,42]. Han et al. [17] observed a significant increase of caspase- 3 activity in juxtaglomerular cells (As4.1 JG) treated with $7 \mu \mathrm{M}$ arsenic trioxide for $48 \mathrm{hr}$ compared to control. To confirm the role of caspase 3 in ATO-induced apoptosis, these investigators also tested the response of ATO-treated As4.1 JG cells in the presence of caspase-3 inhibitor [17,42]. By Western blot analysis, Shim et al. [43] reported that arsenic trioxide $(10 \mu \mathrm{M})$ induced apoptosis through caspase-3 activation in chronic myelogenous leukemia (K562) cells.

It has been pointed out that caspase- 3 is activated by caspase- 9 via activation of BID by caspase- 8 , loss of mitochondrial membrane potential $(\Delta \psi \mathrm{m})$ and cytochrome $\mathrm{c}$ release in the cytosol. This is called the mitochondrial apoptotic pathway [44]. In the present study, we found an up regulation of cytochrome c at $2 \mu \mathrm{g} / \mathrm{ml}$ and a downregulation at 4 and $6 \mu \mathrm{g} / \mathrm{ml}$ ATO (Figure 5C). We also found that there was a strong dose-dependent down regulation of bcl-2 protein expression in A549 exposed to ATO (Figure 5D). This finding is consistent with other studies reporting the involvement of bcl-2 cleavage in the acceleration of chemical-induced cell apoptosis [45]. Contrary to our results Nakagawa et al. [45] observed that colon cancer cells (SWAs) treated with $2 \mu \mathrm{M}$ of arsenic trioxide for $72 \mathrm{hr}$ did not undergo apoptosis. However, they reported in another study that other colon cancer cells (SW480) underwent apoptosis following exposure to ATO at similar treatment dose and time period [46]. They also pointed out that the over-expression of bcl-2 protein could not completely prevent apoptosis induced by ATO. These investigators concluded that arsenic trioxide-induced apoptosis was not mediated via the mitochondria $[46,47]$. From the present study, we believe the arsenic trioxide-induced apoptosis was mediated through the mitochondria pathway which activated caspase 3 .

The $\mathrm{p} 53$ protein is a tumor suppressor gene or protein that controls multiple functions in biologic systems. It has been implicated in the mechanism by which arsenic induces cell-cycle arrest, and DNA damage [48]. The p53 gene has been mapped to chromosome 17 [49] and play a vital role in apoptosis and check point control both at $\mathrm{G}_{1} / \mathrm{S}$ and $\mathrm{G}_{2} / \mathrm{M}$ phases in response to DNA damage [50-52]. The data from our western blot analysis revealed that the p53 protein expression significantly increased from $0-4 \mu \mathrm{g} / \mathrm{ml}$ as shown in Figure 5B. However, our results revealed a slight decrease of $\mathrm{p} 53$ expression at $6 \mu \mathrm{g} / \mathrm{ml}$ of ATO (Figure 5B). Hans et al. [17] observed that p53 expression dramatically increased in the AS4.1 renal cells treated with $1 \mu \mathrm{M}$ of arsenic trioxide [17]. Lui et al. [53] reported that multiple myeloma cells with normal p53 were resistant to arsenic trioxideinduced apoptosis and were arrested in $\mathrm{G}_{1}$ phase.

Stress or heat shock proteins (HSPs) are expressed in response to a wide variety of physiological and environmental insults such as heat, reactive oxygen species or anticancer drugs [54]. The elevated levels of Hsp70 proteins have been linked with inhibition of apoptosis. Cells resistant to chemotherapeutic agents have been associated with elevated levels of Hsp70 proteins. To further examine that ATO induced oxidative stress, the expression of Hsp70 and cfos stress proteins was examined. The western blot analysis revealed a dose response relationship with regard to ATO treatment. There was a strong up-regulation of Hsp70 in ATO-treated cells compared to the control (Figure 5C). This is indicative of the cells undergoing oxidative stress or inflammatory reaction $[55,56]$.

The $\mathrm{c}$-fos protein is the product of $\mathrm{c}$-fos mRNA, a member of a family of immediate early gene (IEG) transcription factors (other members include Jun and Egr-1) also identified as proto-oncogenes. It has been discovered in mutated and oncogenic forms in mouse osteosarcomatogenic retroviruses [57]. These transcription factors are involved in the control of proliferation, differentiation and apoptosis, as well as in the control of responses to stress, and play an important role in organogenesis [58]. Several researchers have reported that arsenite activated the transcription factor $\mathrm{Ap}-1$, as a consequence of increasing the activity of its mitogenic component (cfos and c-jun) $[59,60]$. The cfos western blot results revealed a downregulation at $2-4 \mu \mathrm{g} / \mathrm{ml}$ of arsenic trioxide at $48 \mathrm{hr}$ treatment in (Figure 5F). Our data did not agree with result from Chen and others [42], who reported that low levels of arsenites induced proliferation by over expression of cfos protein [42] We believed the downregulation of cfos at $2-4 \mu \mathrm{g} / \mathrm{ml}$ of arsenic trioxide is a stress response induced by arsenic trioxide in the lung (A549) cells. We did not observed cell proliferation at these levels of exposure.

The single cell gel electrophoresis (comet assay) is an assessment tool used to measure single-strand, double-strand DNA breaks and DNA cleavage in mammalian cells [38]. The length of a comet tail (tail migration), olive tail moment and percent DNA are evidence of DNA damage using the alkaline comet assay. In this study, we used this assay to study DNA damage after $48 \mathrm{hr}$ of A549 cells to arsenic trioxide. The results revealed a dose-dependent increase in percentages of DNA damage, Comet tail length and olive tail moment Figures 6I (A-C). Graham et al. [24] reported an increase in Comet tail length and Comet tail moment after $24 \mathrm{hr}$ exposure of human induced pluripotent stem cells to ATO. Recent study in our laboratory also reported similar findings with colon (HT-29) cells treated with arsenic trioxide for 24 hr [61]. However, the data revealed DNA damage at a higher level of ATO exposure in colon cancer cells compared to lung cancer cells. Hence, lung cancer cells appear to be more sensitive than colon cancer cells to DNA damage caused by arsenic trioxide.

Several studies have shown that ATO is genotoxic, causing DNA damage to human leukemia (HL-60) cancer cells in a dose-dependent 
manner [26,44,62]. Graham et al. (2003) reported that arsenic was highly genotoxic to human keratinocytes, melanocytes, and dendritic cells. Studies have also shown that arsenic-induces DNA damage in human hepatocytes and urothelial cells measured by the comet assay [63] as well as in lymphocytes [64]. Using the alkaline comet assay, Guillamet et al. [65] also reported DNA damage in human lymphoblastoid (TK6) cell exposed to arsenic-containing compounds.

\section{Conclusions}

In conclusion, the results of this research demonstrate that arsenic trioxide causes significant toxicity to lung carcinoma (A549) cells, and its toxic effects seem to be mediated through oxidative, apoptotic and genotoxic mechanisms. The findings in this study also suggest that ATO has the potential to be used as a chemotherapeutic agent in the treatment of non-small cell lung cancer. However, further in vivo studies using animal models of lung tumoriogenesis are needed to confirm the therapeutic spectrum of arsenic trioxide.

\section{Acknowledgements}

This research was supported by a grant from the National Institutes of Health / National Institute on Minority Health and Health Disparities (G12MD007581) through the RCMI Center for Environmental Health at Jackson State University.

\section{Conflict of Interest}

No authors have any conflict of interest relevant to this work. AW has performed the experiments and drafted the manuscript that was reviewed by all authors. JS and $\mathrm{KN}$ have assisted in performing the statistical analysis and data interpretation. PT has supervised the experiment and reviewed the manuscript for submission.

\section{References}

1. Boring CC, Squires TS, Tong T, Montgomery S (1994) Cancer statistics, 1994 CA Cancer J Clin 44: 7-26.

2. Bilello KS, Murin S, Matthay RA (2002) Epidemiology, etiology, and prevention of lung cancer. Clin Chest Med 23: 1-25.

3. Dilda PJ, Hogg PJ (2007) Arsenical-based cancer drugs. Cancer Treat Rev 33: $542-564$

4. American Cancer Society (2009) Cancer Facts and Figures

5. Evens AM, Tallman MS, Gartenhaus RB (2004) The potential of arsenic trioxide in the treatment of malignant disease: past, present, and future. Leuk Res 28: 891-900

6. Jakubowicz-Gil J, Paduch R, Piersiak T, GÅ,owniak K, Gawron A, et al. (2005) The effect of quercetin on pro-apoptotic activity of cisplatin in HeLa cells. Biochem Pharmacol 69: 1343-1350

7. Kumagai T, Shih LY, Hughes SV, Desmond JC, O'Kelly J, et al. (2005) 19-Nor,25(OH)2D2 (a novel, noncalcemic vitamin D analogue), combined with arsenic trioxide, has potent antitumor activity against myeloid leukemia. Cancer Res 65: 2488-2497.

8. Leu L, Mohassel L (2009) Arsenic trioxide as first-line treatment for acute promyelocytic leukemia. Am J Health Syst Pharm 66: 1913-1918.

9. Miller WH Jr (2002) Molecular targets of arsenic trioxide in malignant cells. Oncologist 7 Suppl 1: 14-19.

10. Gewie A (2003) Introduction to Apoptosis. ApoReview 2-26.

11. Steller H (1995) Mechanisms and genes of cellular suicide. Science 267: 14451449.

12. Rojewski MT, Körper S, Thiel E, Schrezenmeier H (2004) Arsenic trioxideinduced apoptosis is independent of CD95 in lymphatic cell lines. Oncol Rep 11: $509-513$.

13. Shen ZY, Shen J, Cai WJ, Hong C, Zheng MH (2000) The alteration of mitochondria is an early event of arsenic trioxide induced apoptosis in esophageal carcinoma cells. Int J Mol Med 5: 155-158.

14. Chow SK, Chan JY, Fung KP (2004) Inhibition of cell proliferation and the action mechanisms of arsenic trioxide (As2O3) on human breast cancer cells J Cell Biochem 93: 173-187.

15. Baj G, Arnulfo A, Deaglio S, Mallone R, Vigone A, et al. (2002) Arsenic trioxide and breast cancer: analysis of the apoptotic, differentiative and immunomodulatory effects. Breast Cancer Res Treat 73: 61-73.

16. Karlsson J, Ora I, Pörn-Ares I, Påhlman S (2004) Arsenic trioxide-induced death of neuroblastoma cells involves activation of Bax and does not require p53. Clin Cancer Res 10: 3179-3188.

17. Han YH, Kim SZ, Kim SH, Park WH (2007) Arsenic trioxide inhibits growth of As4.1 juxtaglomerular cells via cell cycle arrest and caspase-independent apoptosis. Am J Physiol Renal Physiol 293: F511-520.

18. Lin LM, Li BX, Xiao JB, Lin DH, Yang BF (2005) Synergistic effect of all-transretinoic acid and arsenic trioxide on growth inhibition and apoptosis in human hepatoma, breast cancer, and lung cancer cells in vitro. World J Gastroenterol 11: 5633-5637.

19. Kim, HR, Kim, EJ, Yang, SH, et al (2006) Combination treatment with arsenic trioxide and sulindac augments their apoptotic potential in lung cancer cells through activation of caspase cascade and mitochondrial dysfunction. Int $J$ Oncol 28: 1401-1408.

20. Jiang TT, Brown SL, Kim JH (2004) Combined effect of arsenic trioxide and sulindac sulfide in A549 human lung cancer cells in vitro. J Exp Clin Cancer Res 23: 259-262.

21. Jin HO, Yoon SI, Seo SK, Lee HC, Woo SH, et al. (2006) Synergistic induction of apoptosis by sulindac and arsenic trioxide in human lung cancer A549 cells via reactive oxygen species-dependent down-regulation of survivin. Biochem Pharmacol 72: 1228-1236.

22. Tong Q, Zeng F, Zheng L, Zhao J, Lu G (2001) Apoptosis inducing effects of arsenic trioxide on human bladder cancer cell line BIU-87. Chin Med J (Engl) 114: $402-406$

23. Pu YS, Hour TC, Chen J, Huang CY, Guan JY, et al. (2002) Cytotoxicity of arsenic trioxide to transitional carcinoma cells. Urology 60: 346-350.

24. Graham B, Stevens J, Wells P, Sims J, Rogers C, et al. (2014) Enhancement of arsenic trioxide-mediated changes in human induced pluripotent stem cells (IPS). Int J Environ Res Public Health 11: 7524-7536.

25. Graham-Evans B, Cohly HHP, Yu H, Tchounwou PB (2004) Arsenic trioxideinduced genotoxic and cytotoxic effects in human keratinocytes, melanocytes, and dendritic cells . Int J Environ Res Public Health 1: 83-89.

26. Yedjou CG, Tchounwou PB (2007) In-vitro cytotoxic and genotoxic effects of arsenic trioxide on human leukemia (HL-60) cells using the MTT and alkaline single cell gel electrophoresis (Comet) assays. Mol Cell Biochem 301: 123-130.

27. Alarifi S, Ali D, Alkahtani S, Siddiqui MA, Ali BA (2013) Arsenic trioxidemediated oxidative stress and genotoxicity in human hepatocellular carcinoma cells. Onco Targets Ther 6: 75-84.

28. Basu A, Mahata J, Gupta S, Giri AK (2001) Genetic toxicology of a paradoxical human carcinogen, arsenic: a review. Mutat Res 488: 171-194.

29. Gradecka D, Palus J, Wasowicz W (2001) Selected mechanisms of genotoxic effects of inorganic arsenic compounds. Int J Occup Med Environ Health 14: 317-328.

30. Raynal P, Pollard HB (1994) Annexins: the problem of assessing the biologica role for a gene family of multifunctional calcium- and phospholipid-binding proteins. Biochim Biophys Acta 1197: 63-93.

31. Vermes I, Haanaen C, Steffens-Nakken H, Reutelingsperger C (1995) A novel assay for apoptosis. Flow cytometric detection of phosphatidylserine expression on early apoptotic cells using fluorescein labeled Annexin V. J Immunol Methods 184: 39-51.

32. Martin SJ, Reutelingsperger CP, McGahon AJ, Rader JA, van Schie RC, et al. (1995) Early redistribution of plasma membrane phosphatidylserine is a general feature of apoptosis regardless of the initiating stimulus: inhibition by overexpression of Bcl-2 and Abl. J Exp Med 182: 1545-1556.

33. Koopman G, Reutelingsperger CP, Kuijten GA, Keehnen RM, Pals ST, et al. (1994) Annexin $V$ for flow cytometric detection of phosphatidylserine expression on B cells undergoing apoptosis. Blood 84: 1415-1420.

34. Belloc F, Belaud-Rotureau MA, Lavignolle V, Bascans E, Braz-Pereira E, et al. (2000) Flow cytometry detection of caspase 3 activation in preapoptotic leukemic cells. Cytometry 40: 151-160. 
Citation: Walker AM, Stevens JJ, Ndebele K, Tchounwou PB (2016) Evaluation of Arsenic Trioxide Potential for Lung Cancer Treatment: Assessment of Apoptotic Mechanisms and Oxidative Damage. J Cancer Sci Ther 8: 001-009. doi:10.4172/1948-5956.1000379

35. Alnemri ES, Livingston DJ, Nicholson DW, Salvesen G, Thornberry NA, et al. (1996) Human ICE/CED-3 protease nomenclature. Cell 87: 171

36. Patel T, Gores GJ, Kaufmann SH (1996) The role of proteases during apoptosis. FASEB J 10: 587-597.

37. Peterson GL (1979) Review of the Folin phenol protein quantitation method of Lowry, Rosebrough, Farr and Randall. Anal Biochem 100: 201-220.

38. Tice RR, Agurell E, Anderson D, Burlinson B, Hartmann A, et al. (2000) Single cell gel/comet assay: guidelines for in vitro and in vivo genetic toxicology testing. Environ Mol Mutagen 35: 206-221.

39. Lowe SW, Lin AW (2000) Apoptosis in cancer. Carcinogenesis 21: 485-495.

40. Walker AM, Stevens JJ, Tchounwou PB (2008) Arsenic trioxide mediated apoptosis in breast (MCF7) and lung (A549) carcinoma cells. Metal lons in Biol and Med 10: 135-139.

41. Li Y, Qu X, Qu J, Zhang Y, Liu J, et al. (2009) Arsenic trioxide induces apoptosis and G2/M phase arrest by inducing $\mathrm{Cbl}$ to inhibit PI3K/Akt signaling and thereby regulate p53 activation. Cancer Lett 284: 208-215.

42. Chen YC, Lin-Shiau SY, Lin JK (1998) Involvement of reactive oxygen species and caspase 3 activation in arsenite-induced apoptosis. J Cell Physiol 177: 324-333.

43. Shim MJ, Kim HJ, Yang SJ, Lee IS, Choi HI, et al. (2002) Arsenic trioxide induces apoptosis in chronic myelogenous leukemia K562 cells: possible involvement of p38 MAP kinase. J Biochem Mol Biol 35: 377-383.

44. Kumar S, Yedjou CG, Tchounwou PB (2014) Arsenic trioxide induces oxidative stress, DNA damage, and mitochondrial pathway of apoptosis in human leukemia (HL-60) cells. J Exp Clin Cancer Res 33: 42.

45. Fujita N, Tsuruo T (1998) Involvement of Bcl-2 cleavage in the acceleration of VP-16-induced U937 cell apoptosis. Biochem Biophys Res Commun 246: 484-488

46. Nakagawa Y, Akao Y, Morikawa H, Hirata I, Katsu K, et al. (2002) Arsenic trioxide-induced apoptosis through oxidative stress in cells of colon cancer cell lines. Life Sci 70: 2253-2269.

47. Akao Y, Nakagawa Y, Akiyama K (1999) Arsenic trioxide induces apoptosis in neuroblastoma cell lines through the activation of caspase 3 in vitro. FEBS Lett 455: 59-62.

48. Miller WH Jr, Schipper HM, Lee JS, Singer J, Waxman S (2002) Mechanisms of action of arsenic trioxide. Cancer Res 62: 3893-3903.

49. Oren M (1999) Regulation of the p53 tumor suppressor protein. J Biol Chem 274: 36031-36034.

50. Agarwal ML, Agarwal A, Taylor WR, Stark GR (1995) p53 controls both the G2/M and the $\mathrm{G} 1$ cell cycle checkpoints and mediates reversible growth arrest in human fibroblasts. Proc Natl Acad Sci U S A 92: 8493-8497.

51. el-Deiry WS, Harper JW, O'Connor PM, Velculescu VE, Canman CE, et al.
(1994) WAF1/CIP1 is induced in p53-mediated G1 arrest and apoptosis. Cancer Res 54: 1169-1174.

52. Guillouf C, Rosselli F, Krishnaraju K, Moustacchi E, Hoffman B, et al. (1995) p53 involvement in control of G2 exit of the cell cycle: role in DNA damageinduced apoptosis. Oncogene 10: 2263-2270.

53. Liu Q, Hilsenbeck S, Gazitt $Y$ (2003) Arsenic trioxide induces apoptosis in myeloma cells; p53 dependent $\mathrm{G} 1$ or G2/M cell cycle arrest, activation of caspase 8 or caspase 3 and synergy with APO2/TRAIL. Blood 101: 4078-4080.

54. Shen L, Gong F, Tian W, Li W, Zhang F, et al. (2013) Anti-inflammatory effects of arsenic trioxide eluting stents in a porcine coronary model. Biomed Res Int 2013: 937936.

55. Zhou LF, Zhu Y, Cui XF, Xie WP, Hu AH, et al. (2006) Arsenic trioxide, a potent inhibitor of NF-kappaB, abrogates allergen-induced airway hyperresponsiveness and inflammation. Respir Res 7: 146.

56. Garrido C, Schmitt E, Candé C, Vahsen N, Parcellier A, et al. (2003) HSP27 and HSP70: potentially oncogenic apoptosis inhibitors. Cell Cycle 2: 579-584.

57. Piechaczyk M, Blanchard JM (1994) c-fos proto-oncogene regulation and function. Crit Rev Oncol Hematol 17: 93-131.

58. Gomard T, Jariel-Encontre I, Basbous J, Bossis G, Moquet-Torcy G, et al. (2008) Fos family protein degradation by the proteasome. Biochem Soc Trans 36: 858-863.

59. Cavigelli M, Li WW, Lin A, Su B, Yoshioka K, et al. (1996) The tumor promoter arsenite stimulates AP-1 activity by inhibiting a JNK phosphatase. EMBO J 15: 6269-6279.

60. Daum G, Pham J, Deou J (2001) Arsenite inhibits Ras-dependent activation of ERK but activates ERK in the presence of oncogenic Ras in baboon vascular smooth muscle cells. Mol Cell Biochem 217: 131-136.

61. Stevens JJ, Graham B, Walker AM, Tchounwou PB, Rogers C (2010) The effects of arsenic trioxide on DNA synthesis and genotoxicity in human colon cancer cells. Int J Environ Res Public Health 7: 2018-2032.

62. Lynn S, Gurr JR, Lai HT, Jan KY (2000) NADH oxidase activation is involved in arsenite-induced oxidative DNA damage in human vascular smooth muscle cells. Circ Res 86: 514-519.

63. Dopp E, von Recklinghaussen U, Hartmann Stueckradt I, Pollock I, Rabieh S, et al. (2008) Subcellular distribution of inorganic and methylated arsenic compounds in human urothelial cells and human hepatocyes. Drug Metab Disposition 5: 971-979.

64. Tchounwou PB, Yedjou CG, Dorsey WC (2003) Arsenic trioxide-induced transcriptional activation of stress genes and expression of related proteins in human liver carcinoma cells (HepG2). Cell and Mole Biol 49: 1071-1079.

65. Guillamet E, Creus A, Ponti J, Sabbioni E, Fortaner S, et al. (2004) In vitro DNA damage by arsenic compounds in a human lymphoblastoid cell line (TK6) assessed by the alkaline Comet assay. Mutagenesis 19: 129-135. 